\title{
CCK wt Allele
}

National Cancer Institute

\section{Source}

National Cancer Institute. CCK wt Allele. NCI Thesaurus. Code C128852.

Human CCK wild-type allele is located in the vicinity of 3p22.1 and is approximately $8 \mathrm{~kb}$ in length. This allele, which encodes cholecystokinin protein, plays a role in the stimulation of both gallbladder contraction and pancreatic enzyme release. 